ФТИ-2020

\title{
COMPARATIVE ANALYSIS OF STUDENTS' MOTIVATION IN RUSSIA AND CHINA
}

\author{
Daineko L.V. ${ }^{1}$, Sun G. ${ }^{2}$, Karavaeva N. ${ }^{1}$, Yurasova I. ${ }^{1}$, Davy Y. ${ }^{1}$ \\ 1) Ural Federal University named after the first President of Russia B.N. Yeltsin \\ ${ }^{2)}$ North China University of Water Resources and Electric Power \\ E-mail:1.v.daineko@urfu.ru
} China.

The article is devoted to the study of educational motivation of students in Russia and

The choice of University for training and future profession largely determines the future of a person. The educational environment in which a student is located affects the formation of his personality, character, attitude to work and life. Also very important is the team in which the student is for several years. The training process has a significant impact on the professional development of the future specialist.

This study is based on a comparison of the motivation of higher education and choice of future profession among students of the Ural Federal University and the North China University of water resources and hydropower. The article describes the similarity and difference of approaches to the choice of higher education, the reasons for obtaining higher education, the differences in the assessment of the correctness of such a choice. The article was prepared in collaboration with Sun Guofeng, a student (bachelor) of the North China University of water resources and electric power. 